\title{
Three new species of Saturniidae (Lepidoptera) from Central Brazil
}

\author{
Vitor Osmar Becker ${ }^{1}$ \\ Amabílio J. Aires de Camargo ${ }^{2}$
}

\begin{abstract}
Three new species of Saturniidae from Central Brazil are described: Cicia norape Becker (Ceratocampinae), Dysdaemonia concisa Becker, and Rhescyntis reducta Camargo \& Becker (Arsenurinae).

KEY WORDS. Saturniidae, New species, Cerrado, Brazil, Neotropical
\end{abstract}

The Saturniidae moths are represented in the Cerrado region of Central Brazil by 167 species (CAMARGO \& BECKER 1999: 696). Two of these, one belonging to Cicia Oiticica, 1964, and the other to Dysdaemonia Hübner, [1819], are undescribed (CAMARGO \& BECKER 1999: 696). A third undescribed species, belonging to Rhescyntis Hübner, [1819], has been formerly mistaken for R. hippodamia (Cramer, 1777). These new species are described below. Their holotypes, and part of the paratypes, are deposited in the collection of the first author (VOB), other paratypes in the collection of the Centro de Pesquisa Agropecuária dos Cerrados (CPAC), Planaltina, Distrito Federal. Also, it was found that the series of specimens, included in the article mentioned above as Molippa sabina (Walker, 1855), in reality represents two sibling species, this and $M$. flavocrinata Mabilde, $1896[=M$. simillima Jones, 1907], two species that are safely distinguished only by characters of genitalia (JONES 1907: 181). With the addition of these two species to the list, the Saturniidae include 168 species for the Cerrado region.

\section{Ceratocampinae}

\section{Cicia norape Becker, sp. $\mathbf{n}$.}

Figs 1-4

Male (Fig. 1), fore wing length 1.8-2 cm; female (Fig. 2), 2.2-2.4 cm. Opaque white. Antennae light fuscous. Fore coxae and tibiae fuscous above.

Male genitalia (Figs 3-4). Uncus bifid, each branch ending in two small blunt teeth. Medial process of transtilla long, narrow, strongly sclerotized, connected medially by thin membrane. Valvae short, wide, margins nearly parallel, apex oblique; sacculus with a well developed digital process basally. Juxta a broad, nearly square plate with wide indentation distally. Aedoeagus (Fig. 4) curved ventrally;

1) Research Associate, Departamento de Zoologia, Universidade de Brasília. P.O. Box 04525 , 70919-970 Brasília, Distrito Federal, Brazil. E-mail: vbecker@rudah.com.br

2) Centro de Pesquisa Agropecuária dos Cerrados, Embrapa. P.O. Box 08223, 73301-970 Planaltina, Distrito Federal, Brazil. E-mail: amabilio@cpac.embrapa.br 

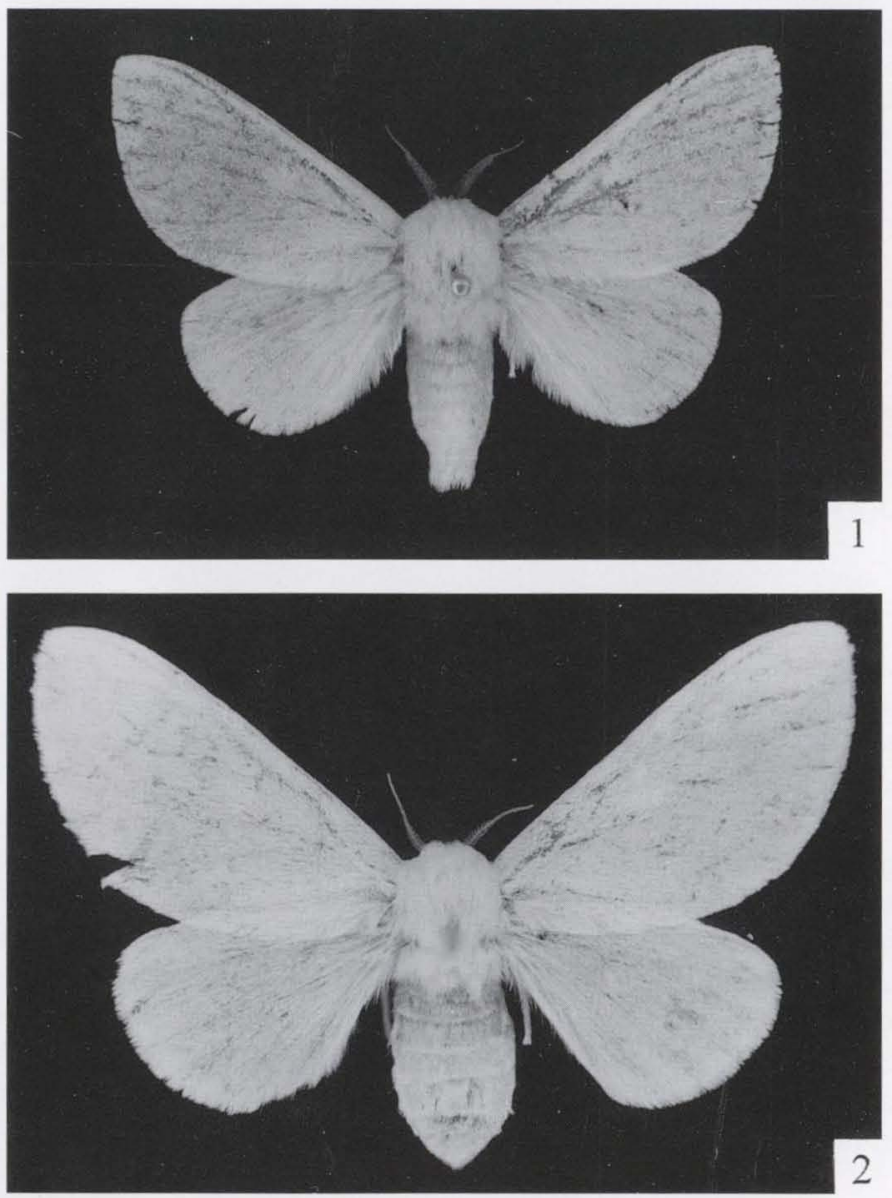

Figs 1-2. Adults of Cicia norape Becker, sp. n., dorsal view. (1) Male holotype; (2) female paratype.

with a thorn ventrally near apex; vesica bearing two thorns, basal slightly larger than that on aedoeagus, distal minute.

Holotype male. BRAzIL: Mato Grosso, Chapada dos Guimarães, 800m, 26.X.1993, Becker leg. [VOB 88942]. Paratypes. 1 female same data as holotype; 2 males, Mato Grosso do Sul, Rio Brilhante, 23-27.X.1970, Becker leg. [VOB 235, 236]; 2 males, same locality, 22-25.I.1971, Becker leg. [VOB 14111]; 1 male, Goiás, Formosa, 800 m, 15.X.1976, Becker leg. [VOB 19949]; 3 males, same locality, 21.X.1976, Becker leg. [VOB 20064]; 1 male, Minas Gerais, Unaí, 700 m, 7. XI.1982, Becker leg. [VOB 49005]; 6 males, 4 females, same locality, 3.XI.1983, Becker leg. [VOB 49595]; 3 males, 1 female, same locality, 21.X.1998, Becker leg. [VOB 117398]; 28 males, 3 females, same locality, 14.X.1999, Camargo leg. [CPAC 16889]. 

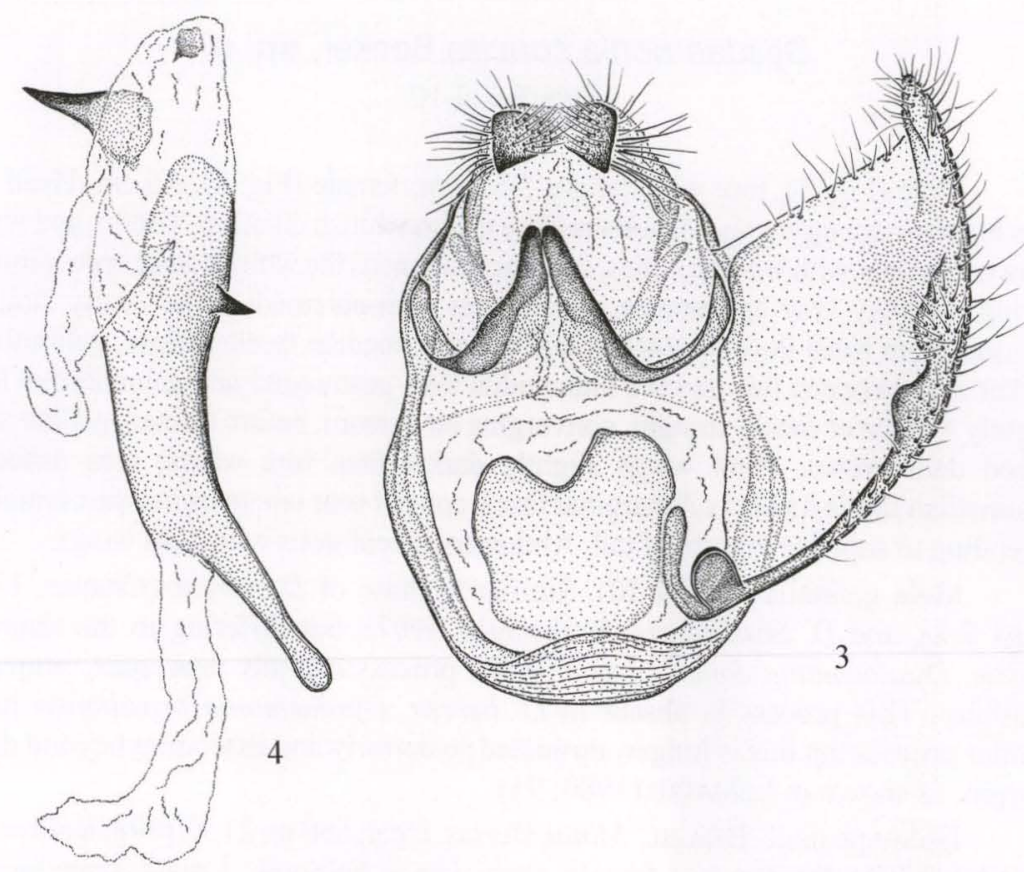

Figs 3-4. Male genitalia of Cicia norape Becker, sp. n.

Remarks. This species resembles some of the large moths belonging to Norape Walker, 1855 (Megalopygidae), especially when in resting position. The only difference is that the species of Norape have a lustrous, sericeus gloss, whereas opaque in the species described here. The male genitalia do not present any clear difference from those of C. citrina (Schaus, 1904) and C. pamala (Schaus, 1900). LEMAIRE (1988: 194-195) also found that the genitalia of the last two show no difference from each other. However, externally the three are remarkably different. Cicia pamala is reddish brown and has a very well defined orbicular dot on the forewings, which is absent in both $C$. citrina and C. norape. Cicia citrina is yellowish and has a faint postmedian fascia, while $C$. norape is wholy white and does not show any trace of fascia. As the three forms are sympatric, at least in part of their range, their biology should be studied to clarify their species status.

Despite being restricted to the Cerrado region of Central Brazil, Cicia norape is not associated with the typical cerrado formations but always collected in the deciduous forests growing on soils derived from limestone. The other two have been collected in typical cerrado formations as well as in gallery forests growing along streams and river banks.

According to the dates of collecting this species is bivoltine, with one generation at the beginning of the rain season (October), and the second at the middle of this season (January), indicating that the larvae of the second generation pupate towards the end of the season, remaining as pupae throughout the dry season, and emerging at the beginning of the following rain season. 


\section{Dysdaemonia concisa Becker, sp. n.}

Figs $5-6,9-10$

Male (Fig. 5), fore wing length 5-5.5 cm; female (Fig. 6), $5.5 \mathrm{~cm}$. Head and legs brown, tarsi light gray. Antennae brown with whitish ciliation. Thorax and wings brown irrorated with whitish scales. In some specimens the whitish scales predominate giving a snowy gray appearance. Fore wings with antemedial line nearly straight, oblique, from basal third of costa to mid dorsum; median fascia diffuse, delimiting a darker area between this and the antemedial line; postmedial and submarginal lines slightly sinuate or nearly straight, converging on dorsum, before tornus; hyaline areas edged dark brown. Hind wings slightly darker than fore wings; area distad of postmedian fascia darker; submarginal fascia convex near tail; marginal fascia arched, extending to superior margin of tail. Abdomen concolorous with hind wings.

Male genitalia (Figs 9-10). Similar to those of $D$. boreas (Cramer, 1775) (Figs 7-8), and D. brasiliensis (Rothschild, 1907), but differing in the shape of valvae. Dysdaemonia concisa has a digital process laterally near apex, projected ventrally. This process is absent in D. boreas. Dysdaemonia brasiliensis has a similar process but this is longer, projected posteriorly and extending beyond distal margin, as shown in LEMAIRE (1980: 95).

Holotype male. BrazIL: Minas Gerais, Unaí, 650 m, 21.X.1998, Becker leg. [VOB 117396]. Paratypes. 1 female, same data as holotype; 1 male, same locality as holotype, 14.X.1999, Camargo leg. (CPAC 16921]; 2 males, Goiás, Formosa, 800 m, 15-20.X.1976, Becker leg. [VOB 19950, 20061]; 1 male, Ceará, Guaramiranga, 1000 m, 9.IV.1994, Becker leg. [VOB 92223]; 3 males, Bahia, Barreiras, $500 \mathrm{~m}, 20 . \mathrm{II} .1996$, Camargo leg. [VOB 89918].

Remarks. The first two specimens collected (VOB 19950, 20061) were for a long time regarded as reduced sized individuals of $D$. boreas (Cramer, 1775). However, the collecting of further specimens, also with reduced size, from different localities, led to the suspicion that they represented a closely related but different species. This is confirmed by the characters of male genitalia, as discussed above.

This species is easily distinguished from the others by size and distribution. All specimens studied have fore wings at least $1 \mathrm{~cm}$ shorter than those of the others. LEMAIRE (1980: 94) mentioned that he also studied small specimens and listed "Mato Grosso" as one of the localities. In case these small specimens came from Mato Grosso, they might represent $D$. concisa.

The three closely related species of the genus $-D$. boreas, $D$. brasiliensis and $D$. concisa - are alopatric and associated with different ecological habitats. The first is a tropical species, associated with the lowland humid forests, from Southern Mexico to the Amazons. The second is distributed along the humid, subtropical, Atlantic forests of Southern Brazil, from Rio de Janeiro to Santa Catarina. Cicia concisa is restricted to the Cerrado region of Central Brazil and the caatinga of Northeast. However, despite being found only in this region, this is another species not associated with the typical cerrado vegetation, but with the deciduous forests growing on soils derived from limestone. The specimen from Ceará, Guaramiranga, 

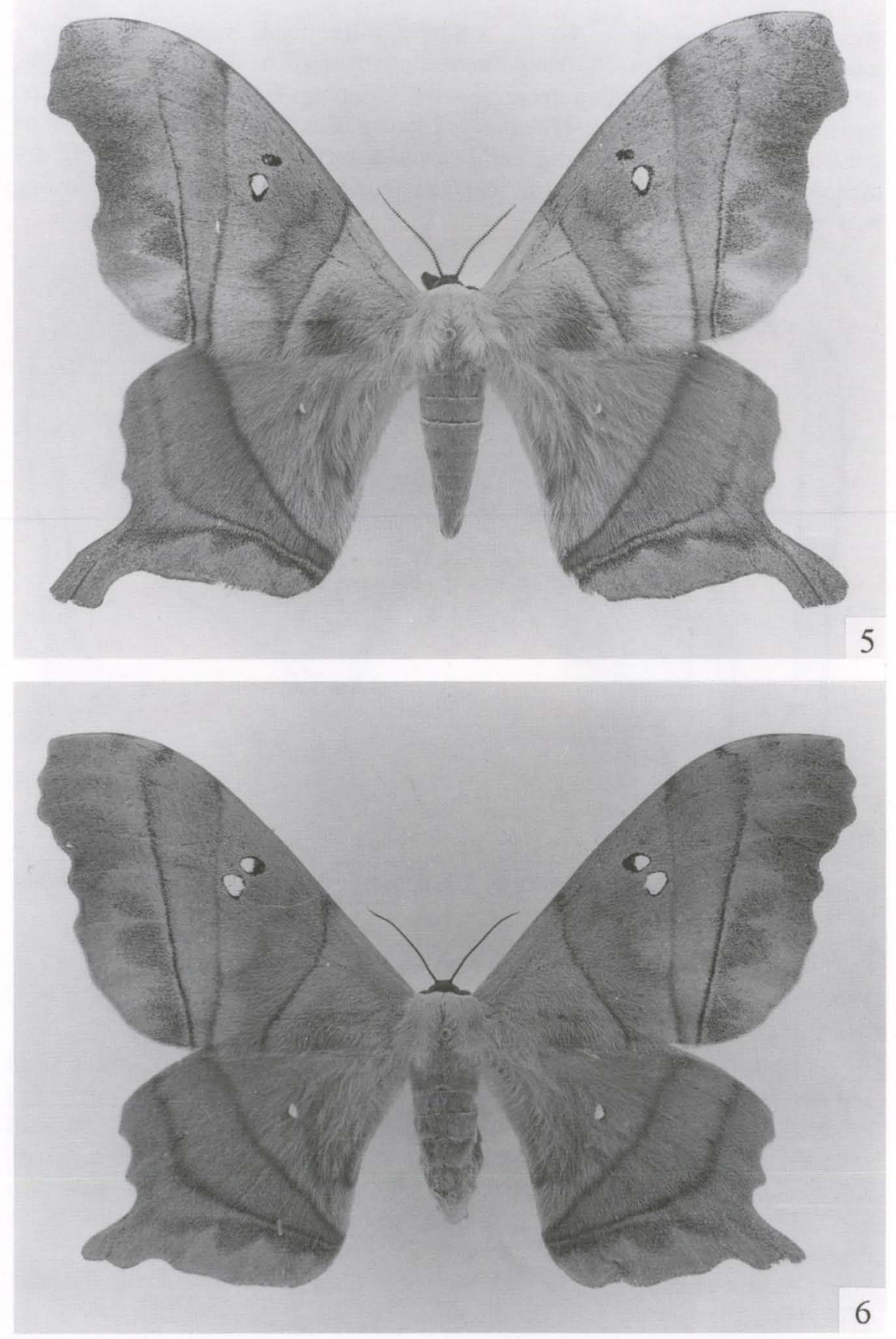

Figs 5-6. Adults of Dysdaemonia concisa Becker, sp. n., dorsal view. (5) Male holotype; (6) female paratype. 
was collected in a similar habitat, a mountain deciduous forest sorrounded by caatinga in the lowlands. The dates of collecting suggest that this species is bivoltine, with the first adult generation emerging at the beginning of the rain season (October) and the second in mid season (February). This indicates that the larvae of the second generation pupate towards the end of the rain season (April-May) spending the dry season (May-September) as pupae, and emerging at the beginning of the following rain season.
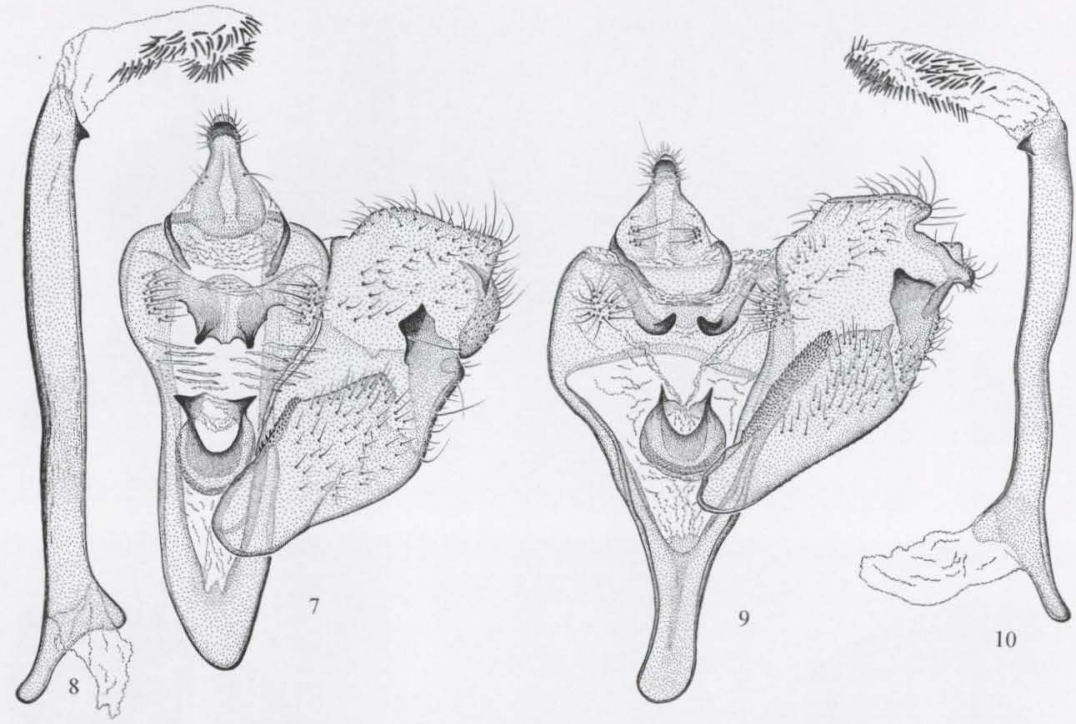

Figs 7-10. Male genitalia of Dysdaemonia. (7-8) D. boreas (Cramer); (9-10) D. concisa Becker, sp. $\mathbf{n}$.

\section{Rhescyntis reducta Camargo \& Becker, sp. n.}

Figs 11-14

Male (Fig. 11), fore wing length 6-6.5 cm; female (Fig. 12), 5.7-7 cm. Head and fore legs dark brown. Thorax and abdomen brown. Wings brown; fore wings irrorated with gray scales basad of median fascia, and with whitish scales distad of submarginal fascia; antemedial fascia vestigial to almost absent. Hind wings with antemedial fascia absent.

Females more brownish. Fore wings with area distad of submarginal fascia irrorated violaceous, instead of whitish.

Male genitalia (Figs 13, 14). Similar to those of D. hippodamia (Cramer, 1777) (Fig. 15).

Holotype male. BRAZIL: Maranhão, Balsas, 525 m, 6-9.II.1997, Camargo leg. [VOB 120452]. Paratypes. 6 males, 3 females, same locality, 6-27.II.1996, 6-9.II.1997, 11-16.II.1998, 3.II.2000, Camargo leg. [VOB 120451-120454, CPAC]. 

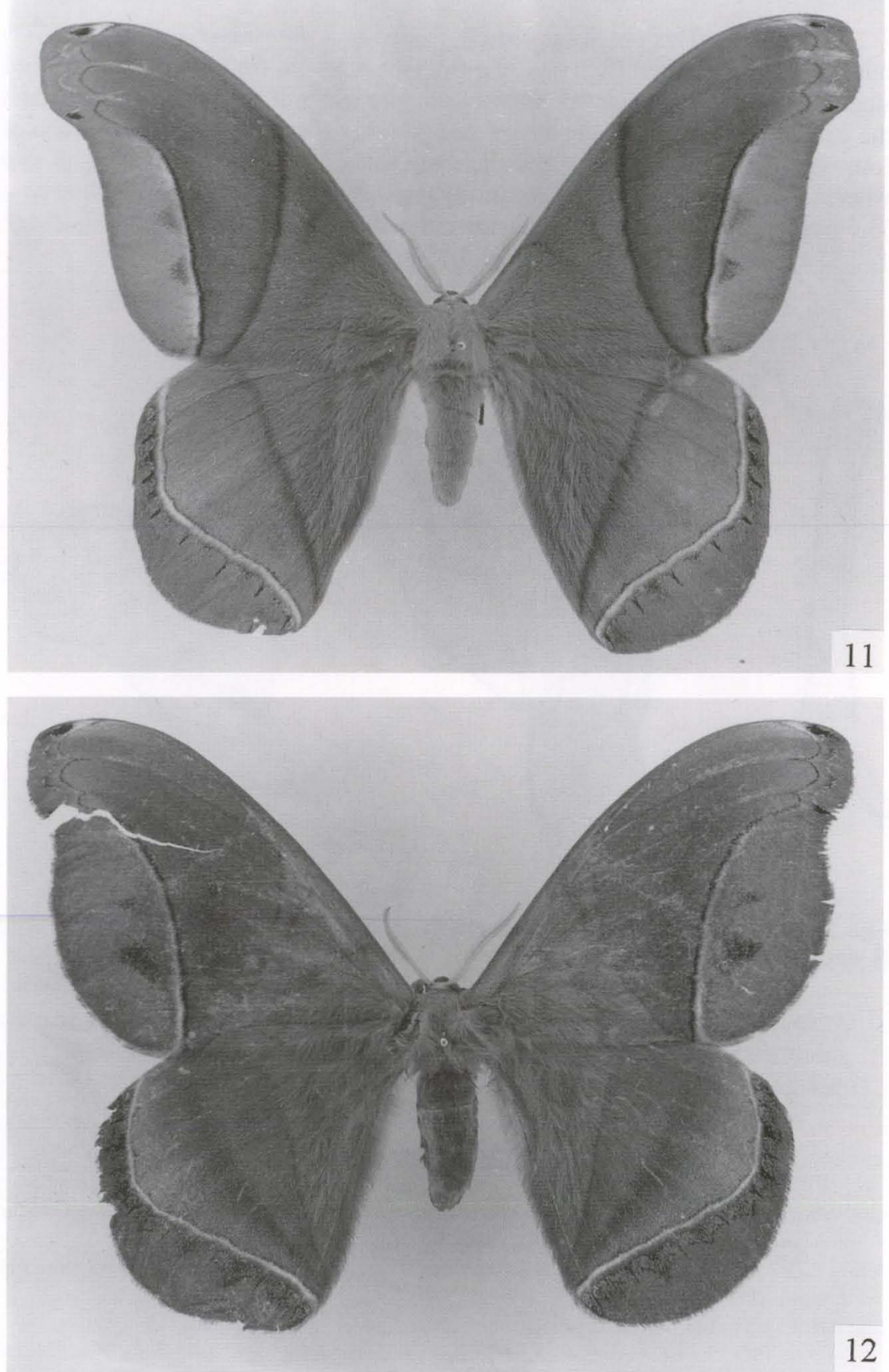

Figs 11-12. Adults of Rhescyntis reducta Camargo \& Becker, sp. n., dorsal view. (11) Male holotype; (12) female paratype. 
Remarks. This species is closely related to R. hippodamia (Cramer, 1777) but easily distinguished from this, and from the others in the genus, by its reduced size. The largest $R$. reducta specimens have fore wings at least $1.5 \mathrm{~cm}$ shorter than the smallest specimens of the others. Also, in R. reducta the antemedial fascia of fore wings is almost missing, and the three apical teeth are almost of equal size whereas in R. hippodamia the third (lowest) is distinctly smaller than the other two. The similarity in genitalia is a character of the genus, as pointed by LEMAIRE (1980: 147-154), showing almost no interspecific differences.
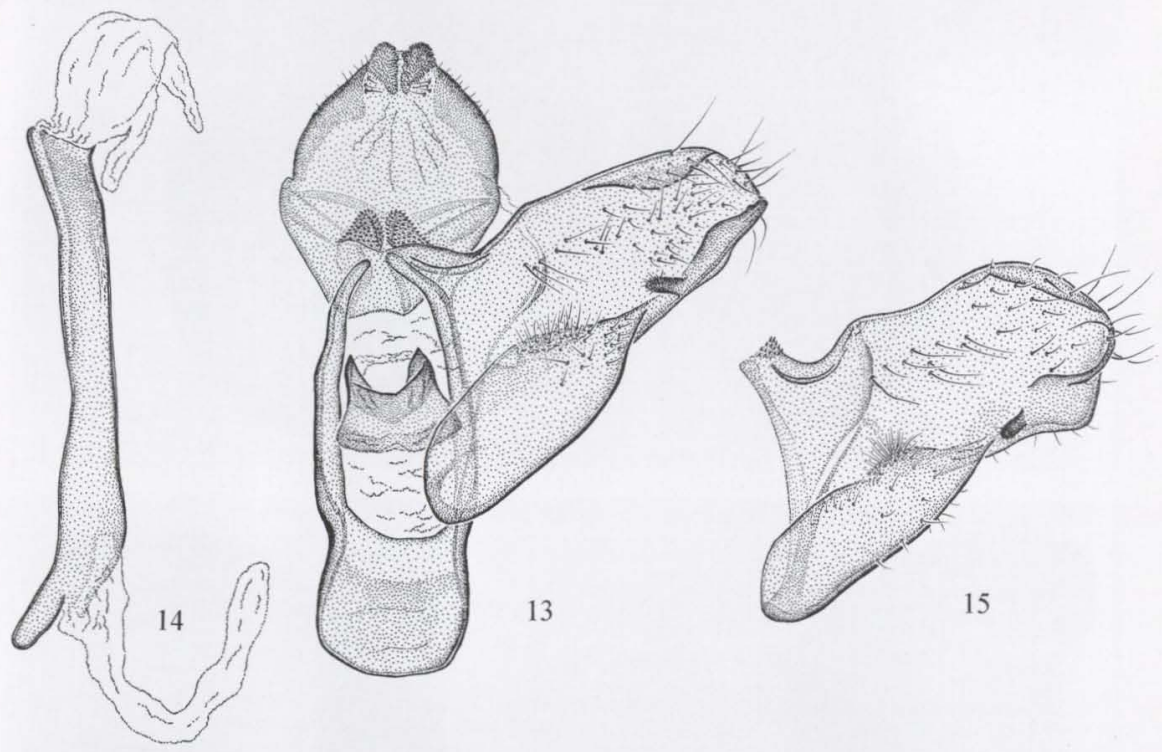

Figs 13-15. Male genitalia of Rhescyntis. (13-14) R. reducta Camargo \& Becker, sp. n.; (15) R. hippodamia (Cramer), right valva.

ACKNOWLEDGEMENTS. The authors are most gratefull to Wellington Cavalcanti, staff artist (CPAC), for producing the line drawings, and to Antonio L.L. Gomes, technician (CPAC), for helping in the preparation of specimens.

\section{REFERENCES}

Camargo, A.J.A. de \& V.O. Becker. 1999. Saturniidae (Lepidoptera) from the Brazilian Cerrado: composition and biogeographic relationships. Biotropica 31: 696-705.

JONES, E.D. 1907. On the remarkable resemblance between two species of Molippa. Trans. ent. Soc.

London 1907: 181-182.

Lemaire, C. 1980. Les Attacidae Americains. Arsenurinae. Neuilly-sur-Seine, France, Author, 199p. 1988. Les Saturniidae Americains. Ceratocampinae. San José, Costa Rica, Museo Nacional, 480p.

Recebido em 16.III.2000; aceito em 05.IV.2001

Revta bras. Zool. 18 (1): 163 - 170, 2001 